Please do not remove this page

RMIT

UNIVERSITY

\title{
Feedwater coagulation to mitigate the fouling of a ceramic MF membrane caused by soluble algal organic matter
}

Zhang, Xiaolei; Fan, Linhua; Roddick, Felicity

https://researchrepository.rmit.edu.au/esploro/outputs/9921859718001341/filesAndLinks?institution=61RMIT_INST\&index=null

Zhang, X., Fan, L., \& Roddick, F. (2014). Feedwater coagulation to mitigate the fouling of a ceramic MF membrane caused by soluble algal organic matter. Separation and Purification Technology, 133, 221-226. https://doi.org/10.1016/j.seppur.2014.06.053

Document Version: Accepted Manuscript

Published Version: https://doi.org/10.1016/j.seppur.2014.06.053

Repository homepage: https://researchrepository.rmit.edu.au

(C) 2014 Elsevier B.V. All rights reserved.

Downloaded On 2023/04/26 19:46:35 +1000 
Thank you for downloading this document from the RMIT Research Repository.

The RMIT Research Repository is an open access database showcasing the research outputs of RMIT University researchers.

RMIT Research Repository: http://researchbank.rmit.edu.au/

\section{Citation:}

Zhang, X, Fan, L and Roddick, F 2014, 'Feedwater coagulation to mitigate the fouling of a ceramic MF membrane caused by soluble algal organic matter', Separation and Purification Technology, vol. 133, pp. 221-226.

See this record in the RMIT Research Repository at:

https://researchbank.rmit.edu.au/view/rmit:24750

Version: Accepted Manuscript

Copyright Statement: (c) 2014 Elsevier B.V. All rights reserved.

Link to Published Version:

http://dx.doi.org/10.1016/j.seppur.2014.06.053 


\section{Abstract:}

\title{
Feedwater coagulation to mitigate the fouling of a ceramic MF membrane caused by soluble algal organic matter
}

\author{
Xiaolei Zhang, Linhua Fan*, Felicity A. Roddick \\ School of Civil, Environmental and Chemical Engineering, RMIT University, \\ GPO Box 2476, Melbourne, VIC 3001, Australia \\ "Corresponding author. Tel: +6139925 3692; fax: +61396390138. \\ E-mail address: linhua.fan@rmit.edu.au
}

Soluble algal organic matter $(A O M)$ resulted from the cyanobacterial blooms in water catchments can cause severe fouling of ceramic membranes in water treatment. The effect of feedwater coagulation using alum, aluminium, $\mathrm{ACH}$, ferric sulphate and ferric chloride for reducing the fouling of a commercial ceramic MF membrane $\left(\mathrm{ZrO}_{2}-\mathrm{TiO}_{2}\right)$ caused by the $\mathrm{AOM}$ released from Microcystis aeruginosa was investigated. At their optimum dosages (i.e., 5 $\mathrm{mg} \mathrm{Al}{ }^{3+} / \mathrm{L}$ and $\left.10 \mathrm{mg} \mathrm{Fe}{ }^{3+} / \mathrm{L}\right)$, all coagulants could significantly mitigate the membrane fouling, with the hydraulically reversible and irreversible fouling resistance reduced by over $90 \%$ and $65 \%$, respectively. $\mathrm{ACH}$, ferric chloride and ferric sulphate performed similarly in reducing the flux decline, and considerably better than alum did. The reduction in AOM fouling of the membrane was primarily due to the effective removal of the very high MW biopolymers (>>20,000 Da). There were much greater removals in carbohydrate $(74-77 \%)$ than protein content $(15-28 \%)$ by the coagulation. The hydrophobic compounds in the AOM solution were more susceptible to the coagulation treatment than the hydrophilic and transphilic compounds. Among the tested coagulants, $\mathrm{ACH}$ appeared to be more costeffective in maintaining the permeate flux and minimising the irreversible fouling for the ceramic MF membrane.

Keywords: Microfiltration; algal organic matter; ceramic membrane; fouling; water treatment 
Ceramic microfiltration (MF) and ultrafiltration (UF) membranes are increasingly utilised in water and wastewater treatment due to their inherent advantages such as high mechanical stability, chemical stability and high hydrophilicity over conventional lowpressure polymeric membranes [1, 2]. However, membrane fouling due to the attachment of aquatic organic matter on the surface and/or inner structures of the membranes remains a major issue limiting the efficiency of ceramic membrane water treatment systems [3].

Blooms of cyanobacteria (also referred to as blue-green algae) occur frequently in many drinking water catchments and result in the release of a substantial amount of soluble algal organic matter $(\mathrm{AOM})$ to the downstream water treatment systems, causing great concerns about water quality and treatment efficiency [4]. The predicted increase in average temperature due to climate change is likely to lead to a higher frequency of cyanobacterial blooms in the future [5]. The AOM released from the cyanobacteria is usually hydrophilic in nature and comprises mainly proteins and polysaccharides [6] which have been demonstrated to have high fouling potentials for both polymeric and ceramic water treatment membranes. The membrane fouling caused by AOM led to severe permeate flux decline in constant transmembrane pressure filtration or significant pressure increase in constant flux mode [6-9]. A recent study on the AOM fouling of a commercial ceramic MF membrane revealed that the majority of the flux decline was attributed to the very high molecular weight (MW) biopolymer compounds, which resulted in the formation of an outer fouling layer of high filtration resistance [7].

Feedwater pre-treatment is a common approach to transform/remove the high fouling potential components, and consequently mitigate their propensity to foul the water treatment membranes [8]. Among the various pre-treatment methods, chemical coagulation with

54 aluminium based salts or ferric based salts is widely used for the removal of high molecular 
weight organics from water and waste water $[9,10]$. The effectiveness of organic removal through coagulation can be strongly affected by the characteristics of the feedwater, and the type and dose of the coagulant [11]. A previous study showed alum and $\mathrm{ACH}$ could improve the filterability of a biologically treated municipal wastewater containing the AOM derived from Microcystis aeruginosa for a polymeric MF membrane [12]. However, comparison of the effect of the most commonly used water treatment coagulants (such as aluminium and iron based coagulants) in reducing $\mathrm{AOM}$ fouling for ceramic membranes has not been documented.

The aim of the present study is to evaluate the fouling mitigation effect of four widely used water treatment coagulants, i.e., alum, $\mathrm{ACH}, \mathrm{Fe}_{2}\left(\mathrm{SO}_{4}\right)_{3}$ and $\mathrm{FeCl}_{3}$, on the water containing AOM using a lab scale ceramic MF membrane system. The AOM used in the work was extracted from stationary growth phase cultures of Microcystis aeruginosa which is the most prevalent cyanobacterium worldwide [13]. The effect of the coagulation on membrane fouling was characterised in terms of reduction in reversible and irreversible fouling resistance, dissolved organic carbon, carbohydrate and protein contents. Advanced organic characterisation techniques including size exclusion chromatography (SEC) using liquid chromatography with organic carbon detection (LC-OCD), fluorescence excitationemission matrix (EEM) spectra and fractionation using resin adsorption chromatography were also employed, with a view to obtaining better insights into the effect of coagulation on fouling mitigation.

\section{Experimental}

2.1. Cultivation of cyanobacteria, AOM extraction and preparation of feed solutions M. aeruginosa (CS 566/01-A01) was purchased from the CSIRO Microalgae Research Centre (Tasmania, Australia). The algal cultures were grown in $5 \mathrm{~L}$ Schott bottles using MLA medium [14] under humidified aeration. The cultures were placed in an incubator 
at the temperature of $22{ }^{\circ} \mathrm{C}$ under illumination for $12 \mathrm{~h} /$ day. The $A O M$ was extracted from

83

84

85

86

87

88

89

90

91

92

93

94

95

96

97

98

99

100

101

102

103

104

105

106

107

cultures harvested after 35th day of growth (stationary growth phase) by centrifugation (3270 $\times \mathrm{g}$ for $30 \mathrm{mins}$ ) of the cell suspensions, and the subsequent filtration of the supernatant using $1 \mu \mathrm{m}$ membranes (Whatman ${ }^{\circledR}$ Grade GF/A). To mimic the presence of AOM in drinking water, the extracted $\mathrm{AOM}$ was diluted to a DOC concentration of $4.3 \pm 0.2 \mathrm{mg} / \mathrm{L}$ with tap water $(1.4 \pm 0.05 \mathrm{mg} \mathrm{DOC} / \mathrm{L})$ to make the feedwater for the coagulation or MF tests. The $\mathrm{pH}$ of the $\mathrm{AOM}$ solution was adjusted to $8.0 \pm 0.2$ using $1 \mathrm{M} \mathrm{HCl}$ or $1 \mathrm{M} \mathrm{NaOH}$ prior to the coagulation tests.

\subsection{Microfiltration tests}

A 7-channel tubular ceramic $\mathrm{ZrO}_{2}-\mathrm{TiO}_{2} \mathrm{MF}$ membrane with a nominal pore size of 0.1 $\mu \mathrm{m}$ (CeRAM ${ }^{\mathrm{TM}}$ INSIDE, TAMI Industries) was used in the filtration experiments and operated under dead-end mode. The ceramic membrane surface layer was made of $\mathrm{ZrO}_{2}$ and the support layer was made of $\mathrm{TiO}_{2}$. This membrane surface was considered as hydrophilic $\left(\mathrm{ZrO}_{2}\right.$ based membrane usually has a contact angle less than $\left.20^{\circ}\right)$ due to the presence of surface hydroxyl groups [15]. All filtration runs were carried out at a constant transmembrane pressure (TMP) of $70 \pm 1 \mathrm{kPa}$ at room temperature $\left(22 \pm 2{ }^{\circ} \mathrm{C}\right)$ for $90 \mathrm{~min}$. After each MF test, the membrane was backwashed for 2 minutes with tap water. The same membrane was used for all MF runs, and after each run the membrane was restored by Cleaning in Place (CIP) by using $0.05 \mathrm{M} \mathrm{NaOH}$ and $0.05 \mathrm{M} \mathrm{HNO}_{3}$ solution until the permeate flux reached 170$180 \mathrm{LMH}$. equations:

$$
J=\frac{\Delta P}{\mu R_{\text {total }}}
$$

$$
R_{\text {total }}=R_{\text {reversible }}+R_{\text {irreversible }}+R_{\text {membrane }}
$$


Where $\Delta P$ is the transmembrane pressure; $J$ stands for the permeate flux and $\mu$ is the water viscosity at $22{ }^{\circ} \mathrm{C}\left(0.955 \times 10^{-3} \mathrm{~Pa} \mathrm{~s}\right) . R_{\text {total }}$ refers to the total resistance after MF of an AOM solution, which can be calculated using the permeate flux at the end of the filtration. $R_{\text {reversible }}$

111 is associated with the hydraulically reversible fouling resistance, and can be determined using the flux before and after backwash with tap water. $R_{\text {membrane }}$ is the resistance of a clean membrane, which was determined by the tap water flux prior to the filtration test with an AOM solution. $R_{\text {irreversible }}$ is the hydraulically irreversible fouling resistance, and can be calculated by deducting $R_{\text {reversible }}$ and $R_{\text {membrane }}$ from $R_{\text {total. }}$

\subsection{Coagulation conditions}

Coagulation using $\mathrm{ACH}$ (aluminium chlorohydrate, Megapac 23, 40\% w/w), alum, ferric chloride and ferric sulphate were investigated as the pre-treatment for AOM solution. Coagulation was conducted at room temperature $\left(20 \pm 2^{\circ} \mathrm{C}\right)$ in a laboratory jar tester unit (Phipps and Bird, PB-700) with rapid mixing for $1 \mathrm{~min}$ at $200 \mathrm{rpm}$, followed by slow mixing for $20 \mathrm{~min}$ at $30 \mathrm{rpm}$. A range of dosages $\left(1-20 \mathrm{mg} \mathrm{Al}{ }^{3+} / \mathrm{L}\right.$ or $\left.1-20 \mathrm{mg} \mathrm{Fe}^{3+} / \mathrm{L}\right)$ was tested to determine the optimal dosage for organic removal. After the jar tests, the resultant treated water samples were immediately filtered with $5 \mu \mathrm{m}$ filter (Advantec) to remove the flocs in the coagulated solution and the $\mathrm{pH}$ of the filtrate was adjusted to 8 prior to being fed to the ceramic membrane MF rig.

\subsection{Analytical methods}

DOC and UV absorbance at $254 \mathrm{~nm}\left(\mathrm{UVA}_{254}\right)$ were determined using a Sievers 820 TOC analyser and a UV/Vis spectrophotometer (UV2, Unicam), respectively. pH was measured with a Hach Sension $156 \mathrm{pH}$ meter. The phenol-sulphuric method was used to determine carbohydrate content [16] with D-glucose used as the standard carbohydrate substance. Protein content was measured using the bicinchoninic acid (BCA) method for which the QPBCA QuantiPro ${ }^{\mathrm{TM}}$ BCA Assay Kit (Sigma Aldrich) was utilised. Bovine serum albumin (Sigma Aldrich) was used as the standard protein substance. 
137 Fluorescence excitation-emission matrix (EEM) spectra were obtained using a fluorescence 138 spectrometer (LS 55, PerkinElmer) at an excitation and emission wavelength range of 200$139550 \mathrm{~nm}$. An interpolation method [17] was used to remove the first-order Rayleigh scattering.

140 The second-order Rayleigh scattering was limited by using a $290 \mathrm{~nm}$ emission cut off filter.

141 The fluorescence spectra of deionised water were subtracted from all EEM spectra to 142 remove the Raman scattering and other background noise.

144 The apparent molecular weight distribution of the AOM was determined by SEC with LC$145 \mathrm{OCD}$ at the Water Research Centre of the University of New South Wales, Sydney, 146 Australia. The LC-OCD system (LC-OCD Model 8, DOC-Labor Dr. Huber, Germany) utilised a SEC column (Toyopearl TSK HW-50S, diameter $2 \mathrm{~cm}$, length $25 \mathrm{~cm}$ ) and the chromatograms were processed using the Labview based program Fiffikus (DOC-Labor Dr. Huber, Germany). The details of this technique are described by Huber et al. [18].

Nonionic macro-porous resins (DAX-8 and XAD-4) were employed to separate the organics into hydrophobic (HPO), transphilic (TPI) and hydrophilic (HPI) fractions. More details of the organic matter fractionation procedure can be found elsewhere [19]. All filtration tests were duplicated and analyses triplicated, and reported in terms of mean value and error/standard deviation.

2.5. Membrane fouling analysis using classic filtration models

Hermia's constant pressure filtration models including complete blocking, standard blocking, intermediate blocking and cake filtration have been widely used to interpret the filtration behaviour of dead-end membrane filtration systems [20]. The detailed description of these models can be found from Shen et al. [21]. The equations for these models are shown in Table 1. The identification of the key fouling mechanism in this study was conducted 
by fitting the experimental data to the equations (Eqs. 3-6). The resulting $R$-squared $\left(R^{2}\right)$ value was used to indicate the goodness of the fit.

165

Table1. Equations for classic filtration models [22].

\begin{tabular}{ll}
\hline Law & Equation \\
\hline Complete blocking & $J_{0}-J=a V$ \\
Intermediate blocking & $1 / J-1 / J_{0}=b t$ \\
Standard blocking & $t / V=c t+d$ \\
Cake filtration & $1 / J-1 / J_{0}=e V$
\end{tabular}

167

168 Where $V$ is the cumulative volume of permeate at time $t, J$ and $J_{0}$ represent flux and initial 169 flux respectively. $a, b, c, d$, e are the model parameters, which could be obtained from data 170 fitting.

\section{Results and discussion}

\subsection{Optimum coagulant dosages}

For the two aluminium based coagulants, the organic matter removal increased 175 significantly with increasing the $\mathrm{Al}^{3+}$ dosage from 1 to $5 \mathrm{mg} / \mathrm{L}$, with $70 \%$ and $65 \%$ of DOC

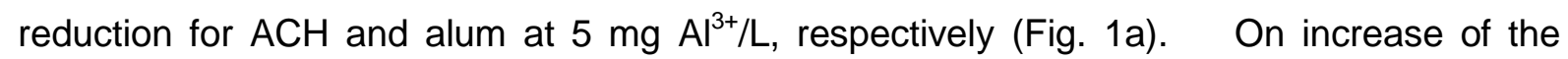
dosages from 10 to $20 \mathrm{mg} \mathrm{Al}^{3+} / \mathrm{L}$, there was no further increase in $\mathrm{DOC}$ reduction for $\mathrm{ACH}$ but a considerable decrease for alum. For the iron based coagulants, the DOC removal increased with increasing iron dosage and was maximium at about $10 \mathrm{mg} \mathrm{Fe}{ }^{3+} / \mathrm{L}$, with approximately $70 \%$ of DOC was removed by the coagulation with the two coagulants. The optimum coagulant dosages in terms of DOC reduction for the AOM solutions were therefore

182 determined as $5 \mathrm{mg} \mathrm{Al}{ }^{3+} / \mathrm{L}$ for $\mathrm{ACH}$ and alum, and $10 \mathrm{mg} \mathrm{Fe}{ }^{3+} / \mathrm{L}$ for $\mathrm{Fe}_{2}\left(\mathrm{SO}_{4}\right)_{3}$ and $\mathrm{FeCl}_{3}$. 183 Coagulation with $\mathrm{ACH}$ did not significantly alter the $\mathrm{pH}$ of the $\mathrm{AOM}$ solutions, and the $\mathrm{pH}$ of 
184 the coagulated water was maintained at around 7 for all dosages (Fig. 1b). Coagulation with 185 alum, $\mathrm{Fe}_{2}\left(\mathrm{SO}_{4}\right)_{3}$ and $\mathrm{FeCl}_{3}$ at their optimum dosages greatly reduced the solution $\mathrm{pH}$. As the 186 solution $\mathrm{pH}$ could affect the MF performance, the $\mathrm{pH}$ of all coagulated solutions was 187 adjusted to 8 prior to all filtration tests for the purpose of a better comparison.
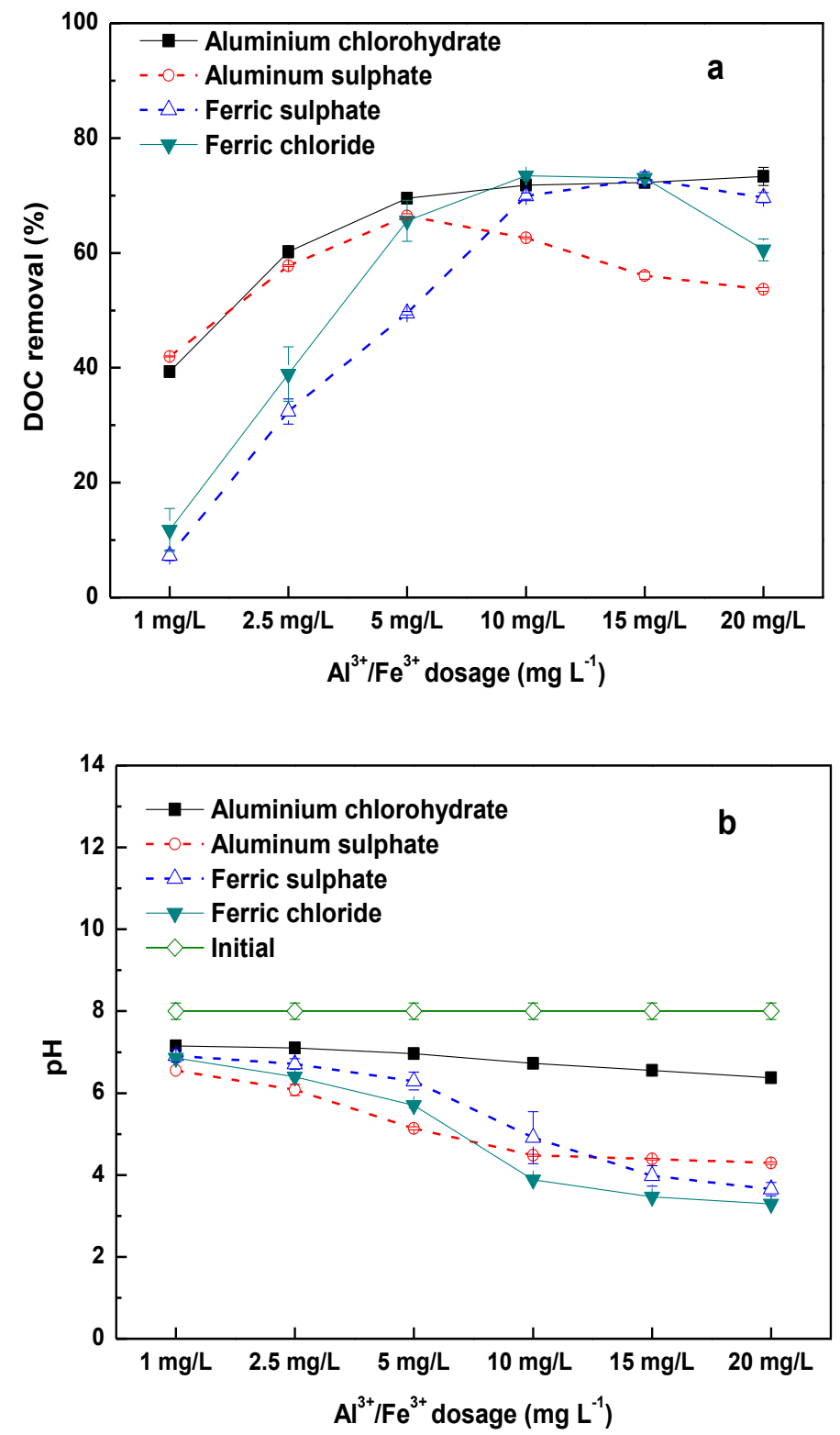

Fig.1 Comparison of DOC removal and pH change for the four coagulants: a) DOC removal, b) $\mathrm{pH}$ of the coagulated $\mathrm{AOM}$ solutions 
The AOM solution without pre-treatment caused rapid and severe flux decline, with 196 approximately 55\% reduction in flux at the end of the filtration (Fig. 2a). Feedwater pre197 treatment by coagulation reduced the flux decline significantly for all coagulants tested, 198 indicating the foulant causing severe flux reduction was effectively removed through the coagulation process. Coagulation with $\mathrm{ACH}$ at $5 \mathrm{mg} \mathrm{Al}{ }^{3+} / \mathrm{L}$ resulted in a slightly higher flux compared with ferric chloride and ferric sulphate at $10 \mathrm{mg} \mathrm{Fe} \mathrm{F}^{3+} / \mathrm{L}$ in the initial $20 \mathrm{~min}$ of 201 filtration. After that the extent of flux reduction for the three coagulants became comparable 202 and approximately $15 \%$ of flux decline was obtained at the end of the filtration. Coagulation 203 with alum at $5 \mathrm{mg} \mathrm{AL}{ }^{3+} / \mathrm{L}$ gave less flux improvement compared with other coagulants, with 204 around $25 \%$ of flux decline at the end of the filtration. Fouling resistance results indicated 205 both reversible and irreversible resistance were reduced markedly due to the coagulation of 206 the feedwater (Fig. 2b). The reduction in hydraulically reversible fouling was comparable for 207 the four coagulants (91-95\%), whereas $\mathrm{ACH}$ and $\mathrm{Fe}_{2}(\mathrm{SO} 4)_{3}$ performed considerably better 208 than alum and $\mathrm{FeCl}_{3}$ in reducing the irreversible fouling.

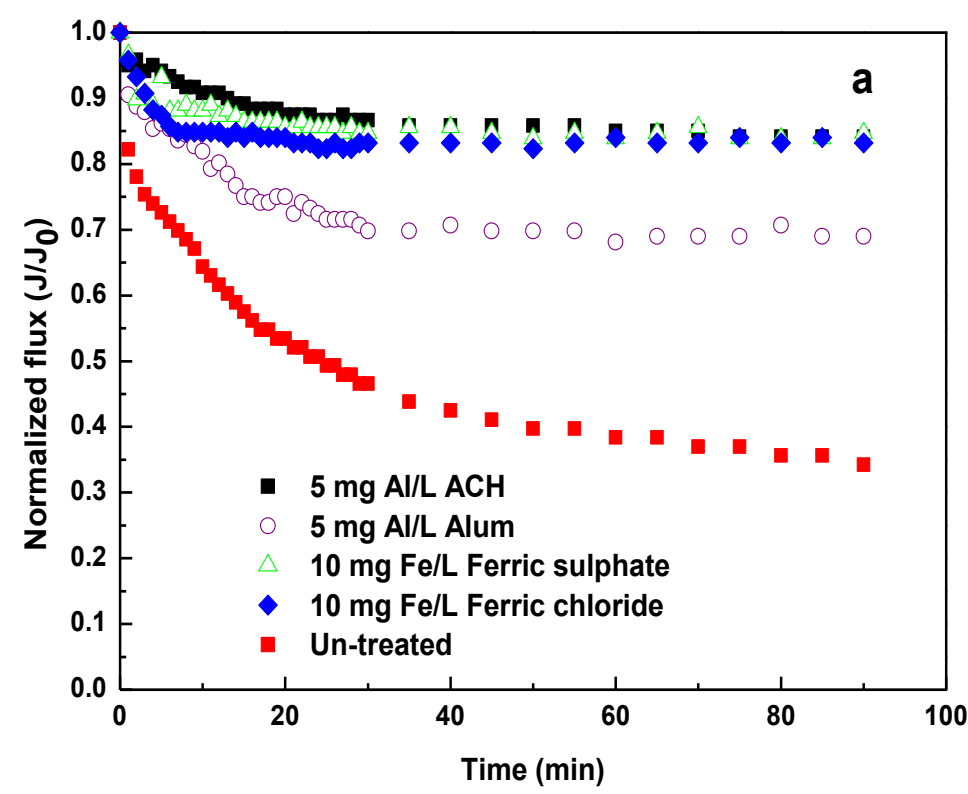




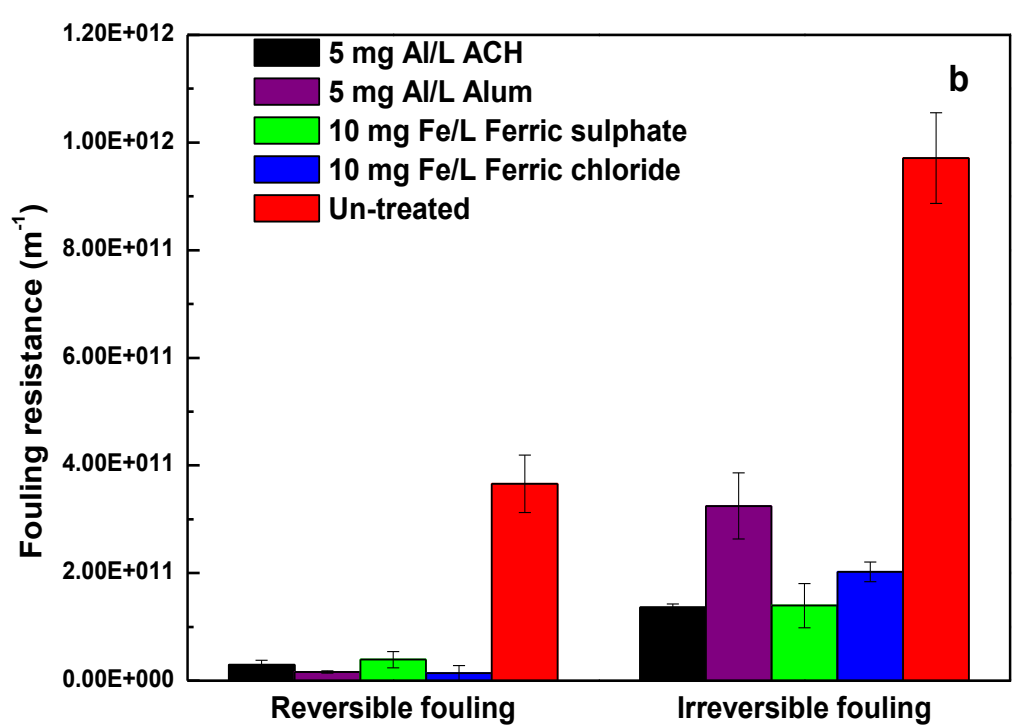

Fig.2 Comparison of (a) flux decline and; (b) fouling resistance in the MF of the uncoagulated and coagulated AOM solutions

3.3 Characterising the effect of coagulation by EEM spectra

Fluorescence EEM spectra have been employed as a useful tool in characterising

217 aquatic organic matter including AOM [23]. EEM spectra can be divided into five regions.

218 Regions I (Ex/Em: 220-270 nm/280-330 nm) and II (Ex/Em: 220-270 nm/330-380 nm) 219 correspond to aromatic proteins (AP), and region III (Ex/Em: $220-270 \mathrm{~nm} / 380-540 \mathrm{~nm}$ ) is associated with fulvic acid (FA)-like substances. Regions IV (Ex/Em: 270-440 nm/280-380 $\mathrm{nm})$ and V (Ex/Em: $270-440 \mathrm{~nm} / 380-540 \mathrm{~nm})$ represent soluble microbial products (SMPs, e.g., proteins and polysaccharide-like materials) and humic acid (HA)-like materials, respectively. The fluorescence regional integration (FRI) method was used to quantify the changes in the fluorescent organic species before and after the coagulation treatment [24]. All four coagulants gave greater reductions in HA-like (58-77\%) and SMP (62-78\%) substances than AP (25-41\%) and FA-like (49-62\%) substances (Fig. 3). Since the HA-like substances in AOM were shown to have less impact on the flux decline for the ceramic MF membrane compared with SMPs and AP [25], the results suggested the flux improvement in this study was primarily due to the removal of the SMPs. The removal in the SMPs by ACH 
$230(77 \%)$ and $\mathrm{FeCl}_{3}(78 \%)$ was greater than for alum (63\%) and $\mathrm{Fe}_{2}\left(\mathrm{SO}_{4}\right)_{3}(62 \%)$, which was 231 consistent with the resultant higher flux for the $\mathrm{ACH}$ and $\mathrm{FeCl}_{3}$ treated water. Although 232 relatively a lower SMP removal was observed for $\mathrm{Fe}_{2}\left(\mathrm{SO}_{4}\right)_{3}$ compared with $\mathrm{ACH}$ and $\mathrm{FeCl}_{3}$, 233 the $\mathrm{Fe}_{2}\left(\mathrm{SO}_{4}\right)_{3}$ treated water exhibited a similar permeate flux as the water treated by $\mathrm{ACH}$ 234 and $\mathrm{FeCl}_{3}$ (Fig. 2a). This was likely attributed to the better removal of $\mathrm{AP}(41 \%)$ and $\mathrm{FA}$ $235(62 \%)$ removal for $\mathrm{Fe}_{2}\left(\mathrm{SO}_{4}\right)_{3}$ than the other coagulants, since these organic substances also 236 have high fouling potentials for the ceramic MF membrane [25] .

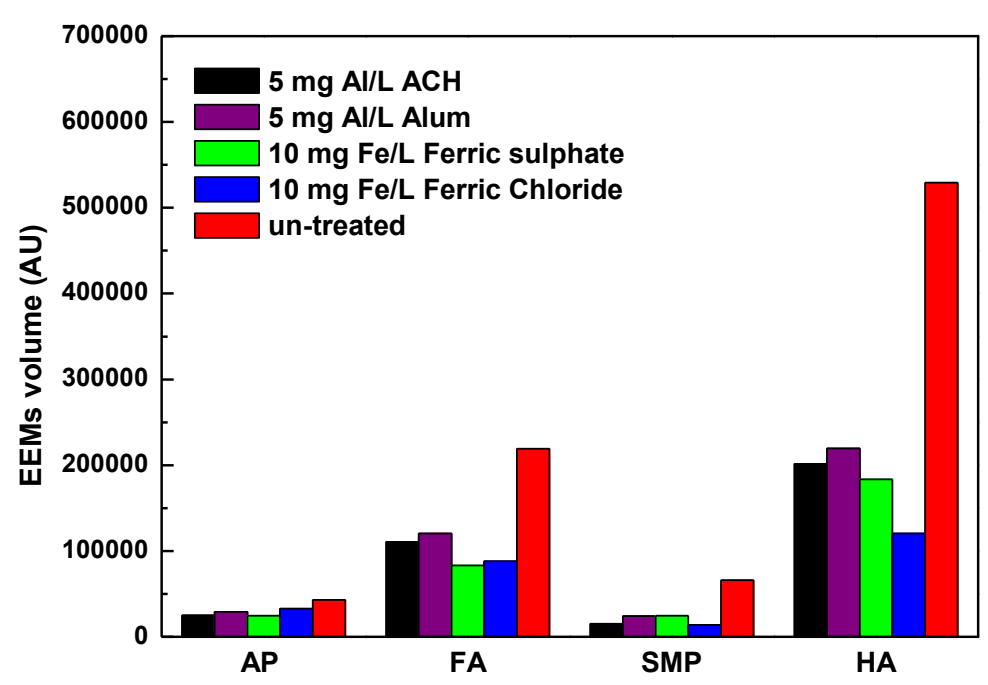

Fig.3 EEM spectra volumes for the AOM solutions before and after coagulation

3.4 Effect of coagulation on molecular weight of AOM The apparent molecular weight distribution of the AOM before and after coagulation 243 treatment was examined using SEC with LC-OCD (Fig. 4). The untreated AOM solution 244 contained significant amounts of very high molecular weight (MW) biopolymers (>> 20,000 245 Da), including two peaks which appeared between 20 and 40 min retention time, mediumMW components (i.e., humic-like substances, 1,000 Da and building blocks, 350-500 Da), and low-MW substances $(<350 \mathrm{Da})$. The organics associated with the second biopolymer peak (at around 38 min retention time) were likely mainly comprised of relatively lower MW 
biopolymers such as small polysaccharides, polypeptides and polyamino acids in the AOM 250 solutions [5].

251

According to the LC-OCD data, over $90 \%$ of the very high MW biopolymers were removed by the coagulation treatments. The iron based coagulants tended to remove more humic-like compounds than the aluminum based coagulants (e.g., $\sim 50 \%$ for $\mathrm{Fe}_{2}\left(\mathrm{SO}_{4}\right)_{3}$ and $\mathrm{FeCl}_{3}$ compared with $42 \%$ and $23 \%$ for alum and $\mathrm{ACH}$ ). The results were consistent with some published studies in which it was observed coagulation tended to remove more macromolecules (such as biopolymers) than medium MW molecules (such as humic-like substances) from the biologically treated municipal wastewater $[9,26]$. The significant reduction in flux decline after the coagulation treatment was therefore attributed to the effective removal of the macromolecules, which helped to mitigate the formation of the highresistance outer fouling layer on the membrane [5].

262

The greater removal of the high MW biopolymers during the coagulation was related to the properties of these molecules. The high MW biopolymers mainly consist of polysaccharides and proteinaceous materials [4]. The high MW polysaccharides (such as transparent exopolymer particles) and proteins contained in AOM are reported to be very surface active, as the metal-binding functional groups (such as carboxyl and hydroxyl groups) in these organics are abundant [27]. Hence they could have strong potential to bind with 269 trivalent metals (such as $\mathrm{Al}^{3+}$ and $\mathrm{Fe}^{3+}$ ) to form larger size complexes [28, 29]. However, other coagulation mechanisms (such as sweep-floc and charge neutralization) may also have contributed to the removal of the biopolymers during coagulation. This would be due to the negatively charged $\mathrm{AOM}$ molecules (measured as $-27 \mathrm{mV}$ under the experimental conditions), the coagulant dosage and solution $\mathrm{pH}(4-7)$ used, which are likely to lead to the removal of the high MW molecules through these mechanisms [30]. 
It was observed that there was an increase in organic compounds with low MW $277(<350 \mathrm{Da})$ after the coagulation, this was probably due to the breaking down of 278 macromolecules or the formation of some metal-organic complexes [31]. These compounds were not likely to be retained by the ceramic MF membrane due to these molecules being significantly smaller than the pore size of the membrane.

282

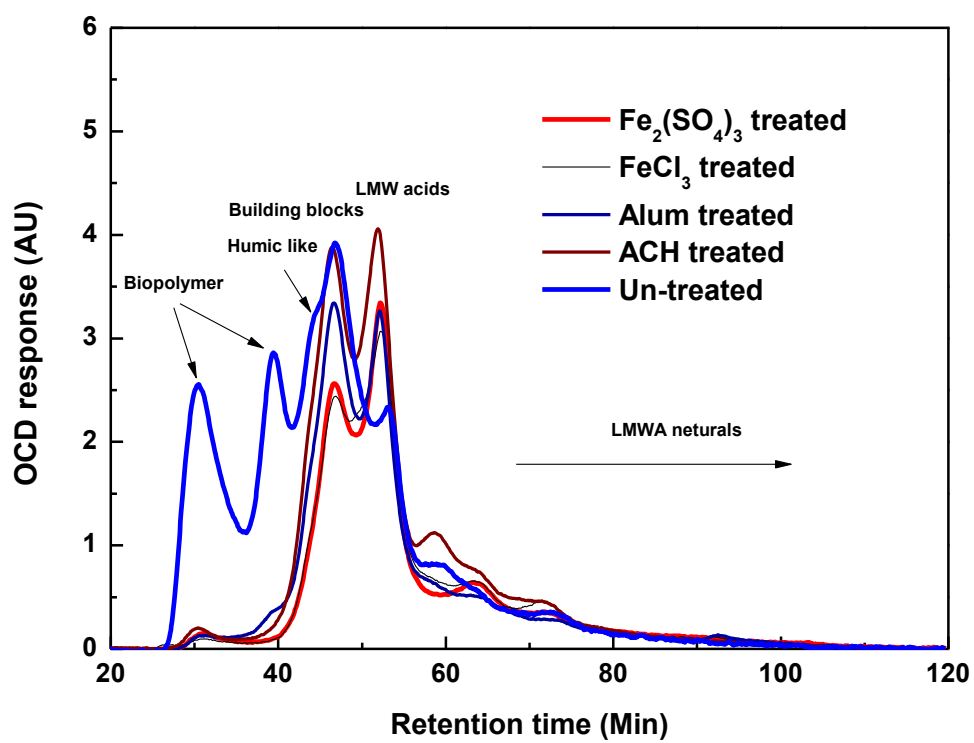

Fig.4. Comparison of LC-OCD chromatograms for the AOM before and after coagulation.

\subsection{Effect of coagulation on carbohydrate and protein removal}

As the biopolymers such as polysaccharides and proteins played an important role in the membrane flux decline, the carbohydrate and protein content of the AOM before and after the coagulation was analysed. The carbohydrate removal was similar for all types of coagulant, with the removal efficiency of $74-77 \%$ (Fig. 5). However, the protein removal efficiency for all types of coagulant was markedly lower (15-28\%). The results suggested the very high MW and high MW molecules removed by coagulation (as indicated in LC-OCD chromatograms) were mainly consisted of carbohydrates (such as polysaccharides) instead of proteins. Hence it appeared that the carbohydrate compounds in the AOM were more susceptible to coagulation treatment. The relatively lower protein removal was probably 

coagulants, which inhibit the coagulation efficiency [32].

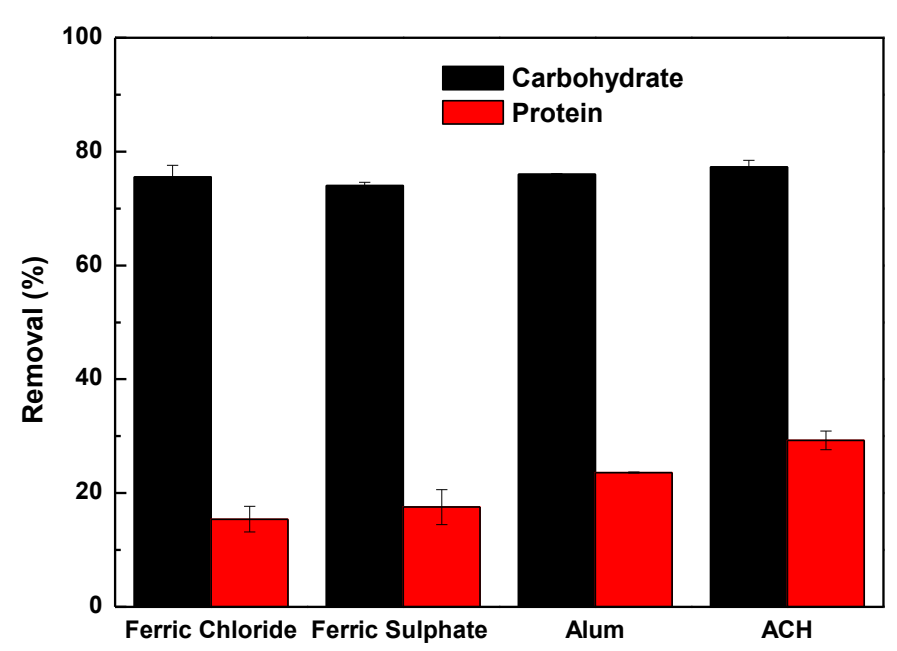

Fig.5 Removal of carbohydrate and protein content from the untreated and coagulated AOM.

300 (The initial carbohydrate and protein concentration in un-treated solution was $5.2 \pm 0.4 \mathrm{mg} / \mathrm{L}$ and $2.0 \pm 0.1 \mathrm{mg} / \mathrm{L}$, respectively.)

302

3.6 Characterising the effect of coagulation by organic matter fractionation

The AOM before and after coagulation was fractionated into different organic groups based on their hydrophobicity using resin adsorption chromatography. Our previous study showed the HPO and HPI fractions of the AOM had significantly higher fouling potentials than TPI in increasing flux decline and irreversible fouling resistance [25]. All coagulants achieved significant reductions in all three fractions (Fig. 6). Coagulation tended to reduce the HPO more than the TPI and HPI, with the average removal efficiencies of $78 \%$ for HPO, $70 \%$ for $\mathrm{TPI}$ and $52 \%$ for $\mathrm{HPI}$. $\mathrm{FeCl}_{3}$ and $\mathrm{Fe}_{2}\left(\mathrm{SO}_{4}\right)_{3}$ gave $85 \%$ and $81 \%$ reduction in $\mathrm{HPO}$ compounds, which were considerably higher than $\mathrm{ACH}(77 \%)$ and alum (69\%). It appeared

312 the iron based coagulants were more effective in removing the HPO compounds compared with the aluminum based coagulants, whereas the HPI removal by the four coagulants was 314 fairly comparable ( $<5 \%$ difference). Although coagulation with $\mathrm{ACH}$ gave a considerably 315 lower removal in HPO compounds compared with the iron based coagulants, it led to a 
316 similar reduction in permeate flux decline as $\mathrm{FeCl}_{3}$ and $\mathrm{Fe}_{2}\left(\mathrm{SO}_{4}\right)_{3}$. This might suggest that

317 the hydrophilic compounds played a more important role in determining the flux performance

318 for the ceramic membrane, since hydrophobic interaction between the organic compounds 319 and membrane materials would not be significant due to the highly hydrophilic nature of the ceramic membrane [5].

321

322

323

324

325

326

327

328

329

330

331

332

333

334

335

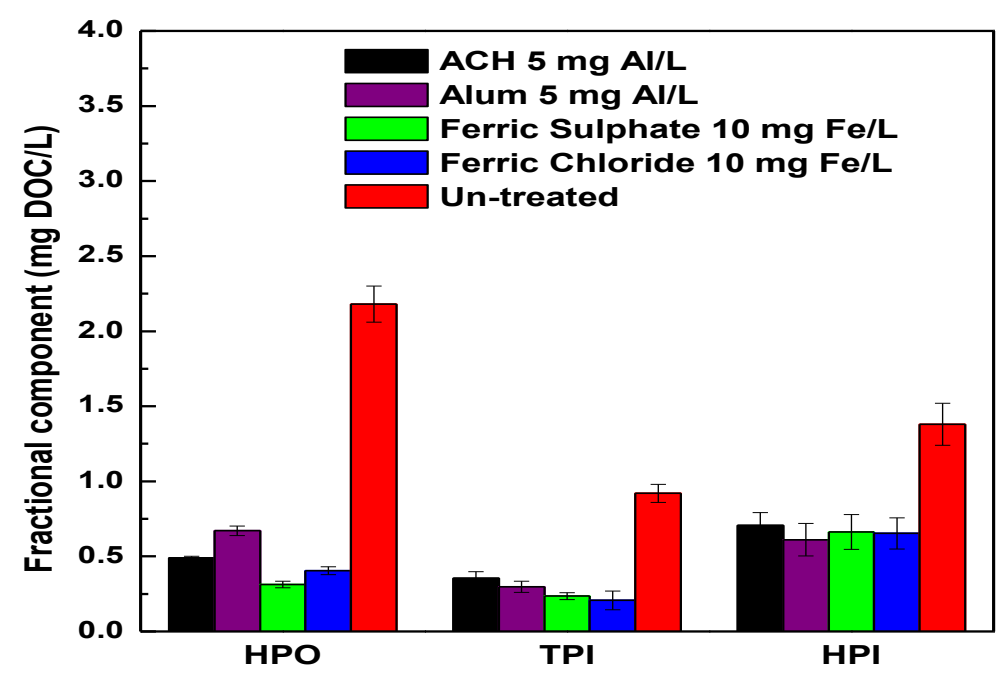

Fig.6 AOM fractions before and after coagulation.

\subsection{Membrane fouling analysis}

In order to investigate the influence of coagulation on the fouling of the ceramic MF membrane in the filtration of the AOM solutions, the classic filtration models were fit by the experimental flux data. The $R^{2}$ values obtained by fitting the flux data were used to indicate the major fouling mechanism for the AOM feed solutions with and without coagulation pretreatment (Table 2).

The best fit (with the highest $R^{2}$ value) of the experimental data for the non-coagulated AOM solution was the cake filtration model. This was consistent with our previous study that the majority of flux decline during the MF of $\mathrm{AOM}$ with the ceramic membrane was attributed to the formation of a cake layer on the membrane surface [7]. The highest $R^{2}$ values for the coagulated AOM feed solutions were given by the intermediate blocking model, except for 
336 the alum-treated solution. The shift of filtration mode before and after coagulation was most

337 likely attributed to the removal of large MW biopolymer molecules during the coagulation

338 process. Therefore, the improved flux resulting from the coagulation with $\mathrm{ACH}, \mathrm{Fe}_{2}\left(\mathrm{SO}_{4}\right)_{3}$

339 and $\mathrm{FeCl}_{3}$ would be due to the mitigation of the formation of a cake layer by the high MW

340 molecules [7].

341

342 The best fit for the alum-treated AOM feed solution was cake filtration. One possible

343 explanation is that the alum-treated AOM solution contained a greater amount of HPO

344 compounds (as shown in Fig.6) compared with the solutions treated with the other

345 coagulants. These HPO compounds may aggregate together on the membrane surface via

346 hydrophobic interaction during the MF process. This mechanism is supported by our

347 previous findings that the HPO compounds played a very important role in cake layer

348 formation on the membrane surface [7]. However, due to the high MW compounds being

349 largely removed from the AOM solution during the coagulation process, the cake layer would

350 be lower in thickness compared with the un-treated AOM solution, resulting in the 351 substantially improved flux.

352

353

Table 2 Summary of the $R^{2}$ values for the AOM solutions with and without coagulation pretreatment.

\begin{tabular}{|c|c|c|c|c|c|}
\hline Model & $\begin{array}{l}\text { Non- } \\
\text { coagulated }\end{array}$ & $\mathrm{ACH}$ & Alum & $\begin{array}{l}\text { Ferric } \\
\text { sulphate }\end{array}$ & $\begin{array}{l}\text { Ferric } \\
\text { chloride }\end{array}$ \\
\hline $\begin{array}{l}\text { Complete } \\
\text { blocking }\end{array}$ & 0.9195 & 0.8808 & 0.8626 & 0.6296 & 0.7931 \\
\hline $\begin{array}{l}\text { Intermediate } \\
\text { blocking }\end{array}$ & 0.9559 & 0.9268 & 0.9003 & 0.8932 & 0.9437 \\
\hline $\begin{array}{l}\text { Standard } \\
\text { blocking }\end{array}$ & 0.9869 & 0.6654 & 0.7488 & 0.6332 & 0.7154 \\
\hline Cake filtration & 0.9884 & 0.9107 & 0.9176 & 0.6705 & 0.9007 \\
\hline
\end{tabular}




\section{Conclusions}

357

358

359

360

361

362

363

364

365

366

367

368

369

370

371

372

373

374

375

376

377

378

379

380

381

The effect of the four commonly used water treatment coagulants (i.e., alum, $\mathrm{ACH}$, ferric sulphate and ferric chloride) on mitigation of the fouling of a ceramic MF membrane caused by the AOM released from Microcystis aeruginosa was investigated. Treatment of the AOM solutions with the four coagulants led to marked reductions in both the reversible and irreversible fouling for the ceramic MF membrane at the optimal coagulant dosages. $\mathrm{ACH}$, ferric chloride and ferric sulphate performed similarly in reducing the flux decline, while alum gave a considerably lower reduction in flux decline. Organic matter characterization using LC-OCD, fluorescence EEMs as well as carbohydrate and protein quantification indicated that the enhanced membrane performance was primarily due to the effective removal of the very high MW biopolymers (>> 20,000 Da) and hence the mitigation of the formation of the thick cake layer on the membrane surface. Although the cost of $\mathrm{ACH}$, ferric chloride and ferric sulphate was fairly comparable (i.e. $\$ 0.03, \$ 0.02$ and $0.04 \mathrm{~kL}^{-1}$, respectively), the iron-based coagulants caused a drastic drop in $\mathrm{pH}$ for the feed water, which would lead to a considerable increase in the treatment cost due to the necessary $\mathrm{pH}$ adjustment. As such, $\mathrm{ACH}$ appeared to be a more cost-effective coagulant in maintaining the performance of the ceramic MF membrane systems during cyanobacterial bloom events. It is suggested that further investigations should be conducted in order to gain a better insight into the key mechanism controlling the removal of the high MW biopolymer molecules, with a view to further optimizing the coagulation process.

References

[1] B. Hofs, J. Ogier, D. Vries, E.F. Beerendonk, E.R. Cornelissen, Comparison of ceramic and polymeric membrane permeability and fouling using surface water, Separation and Purification Technology, 79 (2011) 365-374. 
382 [2] L. Dramas, J.P. Croué, Ceramic membrane as a pretreatment for reverse osmosis: 383 Interaction between marine organic matter and metal oxides, Desalination and Water 384 Treatment, 51 (2013) 1781-1789.

385 [3] S.G. Lehman, L. Liu, Application of ceramic membranes with pre-ozonation for treatment 386 of secondary wastewater effluent, Water Research, 43 (2009) 2020-2028.

387 [4] J. Fang, X. Yang, J. Ma, C. Shang, Q. Zhao, Characterization of algal organic matter and 388 formation of DBPs from chlor(am)ination, Water Research, 44 (2010) 5897-5906.

389 [5] E.S. Reichwaldt, A. Ghadouani, Effects of rainfall patterns on toxic cyanobacterial blooms 390 in a changing climate: Between simplistic scenarios and complex dynamics, Water 391 Research, 46 (2012) 1372-1393.

392 [6] N. Her, G. Amy, H.-R. Park, M. Song, Characterizing algogenic organic matter (AOM) 393 and evaluating associated NF membrane fouling, Water Research, 38 (2004) 1427-1438.

394 [7] X. Zhang, L. Fan, F.A. Roddick, Understanding the fouling of a ceramic microfiltration 395 membrane caused by algal organic matter released from Microcystis aeruginosa, Journal of 396 Membrane Science, 447 (2013) 362-368.

397 [8] H.K. Shon, S. Vigneswaran, S.A. Snyder, Effluent organic matter (EfOM) in wastewater: 398 Constituents, effects, and treatment, Crit. Rev. Environ. Sci. Technol., 36 (2006) 327-374.

399 [9] L. Fan, T. Nguyen, F.A. Roddick, J.L. Harris, Low-pressure membrane filtration of 400 secondary effluent in water reuse: Pre-treatment for fouling reduction, Journal of Membrane 401 Science, $320(2008)$ 135-142.

402 [10] Z. Liang, Y. Wang, Y. Zhou, H. Liu, Coagulation removal of melanoidins from 403 biologically treated molasses wastewater using ferric chloride, Chemical Engineering 404 Journal, 152 (2009) 88-94.

405 [11] M. Kabsch-Korbutowicz, Effect of Al coagulant type on natural organic matter removal 406 efficiency in coagulation/ultrafiltration process, Desalination, 185 (2005) 327-333.

407 [12] Y. Goh, J. Harris, F. Roddick, Impact of Microcystis aeruginosa on membrane fouling in 408 a biologically treated effluent, Water science and technology, 63 (2011) 2853-2859. 
410 Maynard, I. Falconer, Health Effects Of Toxic Cyanobacteria (Blue-Green Algae), in, 411 National Health and Medical Research Council of Australia, 1994.

412 [14] C.J.S. Bolch, S.I. Blackburn, Isolation and purification of Australian isolates of the toxic 413 cyanobacteriumMicrocystis aeruginosa Kütz, Journal of Applied Phycology, 8 (1996) 5-13.

414 [15] N. Gao, M. Li, W. Jing, Y. Fan, N. Xu, Improving the filtration performance of $\mathrm{ZrO}_{2}$ 415 membrane in non-polar organic solvents by surface hydrophobic modification, Journal of 416 Membrane Science, 375 (2011) 276-283.

417 [16] M. Dubois, K.A. Gilles, J.K. Hamilton, P.A. Rebers, F. Smith, Colorimetric method for 418 determination of sugars and related substances, Analytical Chemistry, 28 (1956) 350-356.

419 [17] M. Bahram, R. Bro, C. Stedmon, A. Afkhami, Handling of Rayleigh and Raman scatter 420 for PARAFAC modeling of fluorescence data using interpolation, Journal of Chemometrics, $42120(2006)$ 99-105.

422 [18] S.A. Huber, A. Balz, M. Abert, W. Pronk, Characterisation of aquatic humic and non423 humic matter with size-exclusion chromatography - organic carbon detection - organic 424 nitrogen detection (LC-OCD-OND), Water Research, 45 (2011) 879-885.

425 [19] G.R. Aiken, D.M. McKnight, K.A. Thorn, E.M. Thurman, Isolation of hydrophilic organic 426 acids from water using nonionic macroporous resins, Organic Geochemistry, 18 (1992) 567427573.

428 [20] J. Herima, Constant pressure blocking filtration laws. Application to power-law non429 Newtonian fluids, Trans. Ind. Chem. Eng, 60 (1982) 183.

430 [21] Y. Shen, W. Zhao, K. Xiao, X. Huang, A systematic insight into fouling propensity of 431 soluble microbial products in membrane bioreactors based on hydrophobic interaction and 432 size exclusion, Journal of Membrane Science, 346 (2010) 187-193.

433 [22] F. Qu, H. Liang, J. Zhou, J. Nan, S. Shao, J. Zhang, G. Li, Ultrafiltration membrane 434 fouling caused by extracellular organic matter (EOM) from Microcystis aeruginosa: Effects of 435 membrane pore size and surface hydrophobicity, Journal of Membrane Science, 449 (2014) $436 \quad 58-66$. 
437 [23] R.K. Henderson, A. Baker, S.A. Parsons, B. Jefferson, Characterisation of algogenic 438 organic matter extracted from cyanobacteria, green algae and diatoms, Water Research, 42 $439 \quad$ (2008) 3435-3445.

440 [24] W. Chen, P. Westerhoff, J.A. Leenheer, K. Booksh, Fluorescence Excitation-Emission 441 Matrix Regional Integration to Quantify Spectra for Dissolved Organic Matter, Environmental 442 Science and Technology, 37 (2003) 5701-5710.

443 [25] X. Zhang, L. Fan, F.A. Roddick, Influence of the characteristics of soluble algal organic 444 matter released from Microcystis aeruginosa on the fouling of a ceramic microfiltration 445 membrane, Journal of Membrane Science, 425-426 (2013) 23-29.

446 [26] J. Haberkamp, A.S. Ruhl, M. Ernst, M. Jekel, Impact of coagulation and adsorption on 447 DOC fractions of secondary effluent and resulting fouling behaviour in ultrafiltration, Water 448 Research, 41 (2007) 3794-3802.

449 [27] J.P.L. Kenney, J.B. Fein, Importance of extracellular polysaccharides on proton and Cd 450 binding to bacterial biomass: A comparative study, Chemical Geology, 286 (2011) 109-117.

451 [28] S. Meng, M. Rzechowicz, H. Winters, A.G. Fane, Y. Liu, Transparent exopolymer 452 particles (TEP) and their potential effect on membrane biofouling, Applied microbiology and 453 biotechnology, 97 (2013) 5705-5710.

454 [29] A.M. Mclntyre, C. Guéguen, Binding interactions of algal-derived dissolved organic 455 matter with metal ions, Chemosphere, 90 (2013) 620-626.

456 [30] J.-D. Lee, S.-H. Lee, M.-H. Jo, P.-K. Park, C.-H. Lee, J.-W. Kwak, Effect of coagulation 457 conditions on membrane filtration characteristics in coagulation-microfiltration process for 458 water treatment, Environmental Science \& Technology, 34 (2000) 3780-3788.

459 [31] L. Fan, T. Nguyen, F.A. Roddick, Characterisation of the impact of coagulation and 460 anaerobic bio-treatment on the removal of chromophores from molasses wastewater, Water 461 Research, 45 (2011) 3933-3940.

462 [32] T. Takaara, D. Sano, H. Konno, T. Omura, Affinity isolation of algal organic matters able 463 to form complex with aluminium coagulant, Water Science and Technology, 4 (2004) 95-102. 